\title{
Compatibility of 'soil-variety-fertilizer' to fertilizer norms and dynamics of food elements
}

\author{
Jakhongir Kuziev ${ }^{1, *}$, Alisher Matyakubov ${ }^{2}$, Shavkat Jumaev ${ }^{1}$, and Sobirjon Nizamov ${ }^{1}$ \\ ${ }^{1}$ Research Institute of Soil Science and Agrochemistry, Kamarniso str., Tashkent, Uzbekistan \\ ${ }^{2}$ Tashkent State Agrarian University, University str., 2, Tashkent province, Uzbekistan, 100140
}

\begin{abstract}
This article notes the geographical location and soil-climatic conditions of Kashkadarya province in Uzbekistan, as well as the mechanical composition, agrochemical properties and dynamics of nutrients in the soil of field experiments conducted in the conditions of typical irrigated gray soils in Shakhrisabz district. In total, 36\% of the irrigated soils of the Kashkadarya basin are typical gray soils, and the genetic layers of the soils of the studied area are medium sandy, with large dust particles predominating in the mechanical fraction and create nutritional regimens. In the driving layers of the studied soils, humus $1.094 \%$, total nitrogen $0.080 \%$, total phosphorus $0.168 \%$, total potassium $1.07 \%$, mobile nitrogen, phosphorus and exchangeable potassium belong to low and moderately supplied groups. It is also possible to fully demonstrate the potential of cotton by creating a scientifically based nutrient environment for the promising variety "Porlok-4".
\end{abstract}

\section{Introduction}

The role of soil fertility and high-yielding varieties and modern technologies in improving the well-being of the population, including Uzbekistan, and its appeal to the world community is invaluable $[1,8,9]$. Today, not only Uzbekistan, but all over the world requires the rational use of land and water resources, their conservation, the provision of the population with environmentally safe food on a global scale. Because, according to official data recorded by the FAO, by 2050 the world's population will reach 9.2 billion per capita, and when the food supply of this population is calculated, it is required to produce at least 2 times as much food as today $[1,10,11]$.

Today, opportunities to expand arable land are limited. Therefore, the main focus should be on maintaining and restoring soil fertility while not increasing the productivity of agricultural crops and not harming the environment [3]. However, in recent years, soil fertility, including irrigated soils, has declined, making it impossible to obtain the expected yield. This is due to the fact that scientifically based fertilizer standards and ratios, i.e. 'soilvariety-fertilizer' ratio, which take into account the optimal nutrient environment for intensive crops, the level of nutrient availability of soils, soil-climatic conditions and other

\footnotetext{
* Corresponding author: mmjahongir81@gmail.com
} 
factors, are somewhat neglected. Failure to follow the balance between these factors leads to a decrease in the expected yield or the effectiveness of agro-technical measures $[1,3]$.

Cotton, which occupies a major place among agricultural crops, is now grown in 84 countries around the world. According to the International Cotton Advisory Council (ICAC), 32-34 million hectares have been cultivated worldwide in recent years, with India leading the way in 2013-2014 (11.7 million ha) and China (4.6 million ha), the United States (3.53 million ha), Pakistan (2.914 million ha), Uzbekistan (1.285 million) and Brazil (1.122 million) $[4,5]$. Cotton is also grown in South (1.790 million ha) and North $(0.175$ million ha), Africa and French-speaking Africa (2.447 million ha) [5].

Agricultural crops, especially cotton varieties, require different fertilizer standards, types, ratios (NPK), as the nutrition of varieties depends on soil-climatic conditions [5, 8 , 9]. This fully reflects the potential of varieties by producing the most optimal standards, taking into account the 'soil-variety-fertilizer' ratio, which ultimately creates the opportunity to obtain a quality and weighty crop. The role of mineral fertilizers is invaluable. This is because the FAO Office of the United Nations, when studying the demand for mineral fertilizers in different soil conditions in more than 40 countries around the world, recognizes that mineral fertilizers account for $50-60 \%$ of crop yields, in some cases up to $70 \%[3,6]$.

Hence, the optimal norms and terms of nutrients in cotton are the most important and key factor in increasing the yield of crops, especially cotton [7]. However, today the global changes in soil and climatic conditions and the creation of new varieties pose a number of challenges for agricultural workers, especially agrochemists and soil scientists. Therefore, a comprehensive study of nitrogen, phosphorus, potassium and other nutrients necessary for the nutrition of agricultural crops allows to determine the environmental pollution, the coefficient of fertilizer use of crops and their proportions and duration [7, 12].

Taking into account the above, the purpose of this research is to develop the most optimal fertilizer standards, ratios and timing, taking into account the 'soil-varietyfertilizer' ratio of the promising variety of cotton "Porlok-4".

\section{Materials and methods}

The main part of the Kashkadarya province in the southern part of Uzbekistan of Uzbekistan is occupied by the Kashkadarya basin, which borders Samarkand to the north, Bukhara to the northwest, Surkhandarya to the southeast, Turkmenistan to the southwest, and Tajikistan to the northeast [11]. The Kashkadarya Basin is located on the western edge of the Pamir-Alay Mountains and consists of most of the plains: Kitab-Shakhrisabz Plain in the northeast, Guzar Plain in the west, Karshi Desert in the northwest and Nishan Desert in the south, and Sandikli Sand Desert in the southwest. The plain rises to the northeast, forming the Kitab-Shahrisabz basin between the mountains. From the north-east and southeast the deserts are surrounded by Zarafshan (Koratepa, Chakalikalon mountains) and Gissar mountain ranges (Osmontarosh, Shertog, Yakkabog, Eshakmaydon, Kokbulak, Chakchar, Korasirt, Dehkanabad mountains). The Kitab-Kamashi plain is located in the north-east of the province, the hills of Zarafshan in the north and Gissar ridges in the southeast occupy large areas [11].

In terms of geological structure, the Kashkadarya basin is very complex, and the Zarafshan and Gissar ridges, located in its north-eastern and south-eastern parts, are composed of metamorphic rocks. Also, the south-western slopes of the Hissar ridge are completely covered by Mesozoic and Tertiary deposits, and the regional plain area consists mainly of Quaternary deposits developed over Upper Cretaceous and Tertiary deposits [3].

The peculiar climatic features of Kashkadarya province depend on its geographical location, and the fact that the province is located within the Eurasian continent, in the 
central part of Central Asia, has led to a peculiar sharp continental climate. Climate change plays an important role in the composition of the climate, with Arctic air entering the Central Asian region from the north during the winter months, and sometimes precipitation due to global warming caused by tropical air currents in southwestern cyclones in Iran and Afghanistan [11].

Kashkadarya province, located in the southern part of the country, has a special character with its soil and climatic conditions and ancient agricultural culture. Almost all of the existing soils in Uzbekistan are found in the province. In the Kashkadarya basin, the main irrigated gray soils ( $36 \%$ of the irrigated lands of the basin) are distributed $[5,11]$.

The field experiment was carried out in the U. Ibragimov massif of Shahrisabz district in the conditions of typical gray soils, which are widely irrigated. The coordinates of this experimental area - the geographical location - were determined using a device "GPS-60".

Field research, soil and plant sampling, agrochemical analysis, phenological observations were carried out on the basis of generally accepted methodological guidelines in the field of soil science and agrochemistry. In particular, the Guidelines for the implementation of chemical and agrophysical analyzes in the monitoring of land [4] and special methods "Application of mineral and local fertilizers in cotton", "Methods of field experiments", and "High yield technology in cotton" [2].

\section{Results and discussion}

According to the chemical analysis of the soil sample taken from the genetic layers of the field experimental soils, it was found that the genetic layers consisted mainly of medium sandy soils, the lower 120-217 cm layers of heavy sandy mechanical composition, and large dust particles predominated by mechanical fractions. The $0-120 \mathrm{~cm}$ layers in which the main root system of the crop develops consist of a medium sandy mechanical composition, which allows to create favorable water and nutrient regimes for their growth and development (Table 1).

Table 1. mechanical composition of the typical irrigated gray soil

\begin{tabular}{|c|c|c|c|c|c|c|c|c|c|c|}
\hline \multirow[b]{2}{*}{ \# } & \multirow[b]{2}{*}{$\begin{array}{l}\text { Layer } \\
\text { depth, } \\
\text { cm }\end{array}$} & \multicolumn{8}{|c|}{ Soil particles in $\%$, in $\mathrm{mm}$} & \multirow[b]{2}{*}{ Soil } \\
\hline & & $>0.25$ & $\begin{array}{c}0.25- \\
0.1\end{array}$ & $\begin{array}{l}0.1- \\
0.05\end{array}$ & $\begin{array}{l}\text { 0.05- } \\
0.01\end{array}$ & $\begin{array}{l}\text { 0.01- } \\
0.005\end{array}$ & $\begin{array}{l}0.005- \\
0.001\end{array}$ & $<0.001$ & $\begin{array}{c}\text { Physical } \\
\text { mud } \\
(<0.01 \\
\text { mm })\end{array}$ & \\
\hline \multirow{6}{*}{$-\underset{⿱ 亠 乂}{\Delta}$} & $0-35$ & 1.1 & 0.6 & 13.4 & 42.7 & 15.7 & 13.9 & 12.6 & 42.2 & $\begin{array}{c}\text { Medium } \\
\text { sandy }\end{array}$ \\
\hline & $35-51$ & 0.9 & 0.5 & 12.7 & 42.3 & 15.3 & 14.9 & 13.4 & 43.6 & $\begin{array}{c}\text { Medium } \\
\text { sandy }\end{array}$ \\
\hline & $51-78$ & 1.2 & 0.7 & 14.1 & 45.1 & 13.4 & 12.9 & 12.6 & 38.9 & $\begin{array}{c}\text { Medium } \\
\text { sandy }\end{array}$ \\
\hline & $\begin{array}{l}78- \\
120 \\
\end{array}$ & 1.4 & 1.0 & 15.6 & 45.7 & 16.1 & 10.8 & 9.4 & 36.3 & $\begin{array}{c}\text { Medium } \\
\text { sandy }\end{array}$ \\
\hline & $\begin{array}{c}120- \\
167\end{array}$ & 3.7 & 0.9 & 14.1 & 30.2 & 10.9 & 16.7 & 23.5 & 51.1 & $\begin{array}{l}\text { Severe } \\
\text { sandy }\end{array}$ \\
\hline & $\begin{array}{l}167- \\
217\end{array}$ & 5.3 & 1.2 & 10.8 & 32.4 & 11.7 & 15.3 & 23.3 & 50.3 & $\begin{array}{l}\text { Severe } \\
\text { sandy }\end{array}$ \\
\hline
\end{tabular}

According to the initial agrochemical analysis of typical gray soils irrigated by field experiments, humus $1.094 \%$, total nitrogen $0.080 \%$, total phosphorus $0.168 \%$, total 
potassium $1.07 \%$, mobile nitrogen, phosphorus and exchangeable potassium are low in the driving layer of soils $\left(\mathrm{N}-\mathrm{NO}_{3}\right.$ - less than $20-30 \mathrm{mg} / \mathrm{kg}, \mathrm{P}_{2} \mathrm{O}_{5}$ - less than $15-30 \mathrm{mg} / \mathrm{kg}, \mathrm{K}_{2} \mathrm{O}-$ $200-300 \mathrm{mg} / \mathrm{kg}$ on average) and belonging to the average provided groups. This is due to the fact that the nutrients decrease in a uniform manner from the driving layers to the lower layers (Table 2).

Table 2. Primary agrochemical properties of experimental field soils

\begin{tabular}{|c|c|c|c|c|c|c|c|c|c|}
\hline \multirow{3}{*}{ \# } & \multirow{3}{*}{ 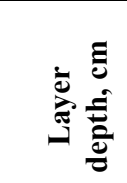 } & \multirow{3}{*}{$\stackrel{\partial}{\hat{\theta}}$} & \multirow{3}{*}{$\frac{\partial}{z}$} & \multirow{3}{*}{ تُ } & \multicolumn{5}{|c|}{ Fertilizers } \\
\hline & & & & & \multicolumn{2}{|c|}{ gross, $\%$} & \multicolumn{3}{|c|}{ reactive, $\mathrm{mg} / \mathrm{kg}$} \\
\hline & & & & & $\mathbf{P}$ & $\mathbf{K}$ & $\mathrm{N}-\mathrm{NO}_{3}$ & $\mathbf{P}_{2} \mathbf{O}_{5}$ & $\mathbf{K}_{2} \mathrm{O}$ \\
\hline \multirow{6}{*}{ 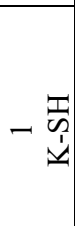 } & $0-35$ & 1.094 & 0.080 & 8.0 & 0.168 & 1.07 & 24.9 & 19.7 & 227 \\
\hline & $35-51$ & 0.851 & 0.068 & 7.3 & 0.145 & 1.05 & 20.9 & 19.2 & 209 \\
\hline & $51-78$ & 0.645 & 0.049 & 7.7 & 0.127 & 1.03 & 19.2 & 11.7 & 184 \\
\hline & $78-120$ & 0.470 & 0.041 & 6.7 & 0.113 & 1.02 & 16.9 & 7.9 & 171 \\
\hline & $120-167$ & 0.430 & 0.045 & 5.5 & 0.106 & 1.01 & 11.0 & 5.0 & 164 \\
\hline & $167-217$ & 0.370 & 0.039 & 5.4 & 0.101 & 0.97 & 8.6 & 4.7 & 149 \\
\hline
\end{tabular}

The ratio of carbon to nitrogen in the studied soil was observed in the range of 5.4-8.0. The ratio of carbon to nitrogen in gray soils occurs in the range of 7-9, the lack of which indicates that the activity of biological processes in soils is slow [1]. The fact that the ratio of carbon to nitrogen in the Ah, Ahay and V1 layers of the experimental field soils is in the range of 7.3-8.0 indicates that it is biologically active.

In the experiment, a promising variety of cotton "Porlok-4" was selected. This variety is early maturing, the growing period and its height averages $110-115$ days $/ \mathrm{cm}$. Its shape is pyramidal, one pod weighs $6.0-6.5 \mathrm{~g}, 1000$ seeds weigh $120 \mathrm{~g}$, and its structure is oval. The fiber belongs to type III, fiber yield is $38 \%$, and fiber length is $36 \mathrm{~mm} \mathrm{[3].}$

The demand, norms and ratios of this cotton to the optimal nutrient conditions in the conditions of typical gray soils, which have long been irrigated by the promising variety "Porlok-4", have not been sufficiently studied. Therefore, in order to fully realize the potential of the variety, using nitrogen, phosphorus and potassium mineral fertilizers in different norms and proportions in the conditions of typical irrigated gray soils in the province of gray soils of the Kashkadarya basin, field experiments were conducted.

The field experiment system is presented in Table 3 below, in which different norms and ratios for nitrogen mineral fertilizers of 250 and $300 \mathrm{~kg} / \mathrm{ha}$ was developed.

Table 3. Field experiment system

\begin{tabular}{|c|c|c|c|c|c|c|c|c|c|}
\hline \multirow{4}{*}{ \# } & \multirow{4}{*}{ 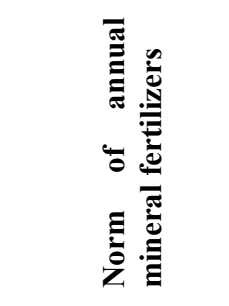 } & \multicolumn{8}{|c|}{ Annual distribution of mineral and local fertilizers, $\mathrm{t} / \mathrm{ha}$ and $\mathrm{kg} / \mathrm{ha}$} \\
\hline & & \multicolumn{2}{|c|}{ 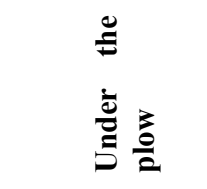 } & \multirow[t]{2}{*}{ 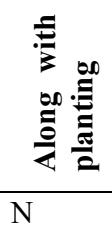 } & \multirow[t]{2}{*}{ 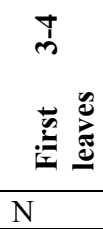 } & \multicolumn{2}{|c|}{ 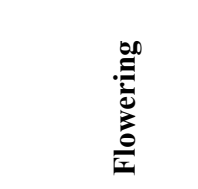 } & \multicolumn{2}{|c|}{ 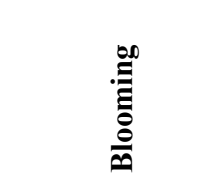 } \\
\hline & & $\mathrm{P}$ & $\mathrm{K}$ & & & $\mathrm{N}$ & $\mathrm{K}$ & $\mathrm{N}$ & $\mathrm{P}$ \\
\hline & & $60 \%$ & $50 \%$ & $25 \%$ & $20 \%$ & $25 \%$ & $50 \%$ & $30 \%$ & $40 \%$ \\
\hline 1 & Control $\left(\mathrm{N}_{0} \mathrm{P}_{0} \mathrm{~K}_{0}\right)$ & - & - & - & - & - & - & - & - \\
\hline 2 & $\mathrm{~N}_{250} \mathrm{P}_{175} \mathrm{~K}_{0}$ & 105 & - & 62.5 & 50 & 62.5 & - & 75 & 70 \\
\hline 3 & $\mathrm{~N}_{250} \mathrm{P}_{0} \mathrm{~K}_{125}$ & 0 & 62.5 & 62.5 & 50 & 62.5 & 62.5 & 75 & - \\
\hline 4 & $\mathrm{~N}_{250} \mathrm{P}_{250} \mathrm{~K}_{250}$ & 150 & 125 & 62.5 & 50 & 62.5 & 125 & 75 & 100 \\
\hline
\end{tabular}




\begin{tabular}{|l|l|l|l|l|l|l|l|l|l|}
\hline 5 & $\mathrm{~N}_{250} \mathrm{P}_{225} \mathrm{~K}_{175}$ & 135 & 87.5 & 62.5 & 50 & 62.5 & 87.5 & 75 & 90 \\
\hline 6 & $\mathrm{~N}_{250} \mathrm{P}_{200} \mathrm{~K}_{150}$ & 120 & 75 & 62.5 & 50 & 62.5 & 75 & 75 & 80 \\
\hline 7 & $\mathrm{~N}_{250} \mathrm{P}_{175} \mathrm{~K}_{125}$ & 105 & 62.5 & 62.5 & 50 & 62.5 & 62.5 & 75 & 70 \\
\hline 8 & $\mathrm{~N}_{250} \mathrm{P}_{150} \mathrm{~K}_{100}$ & 90 & 50 & 62.5 & 50 & 62.5 & 50 & 75 & 60 \\
\hline 9 & $\mathrm{~N}_{300} \mathrm{P}_{210} \mathrm{~K}_{0}$ & 126 & - & 75 & 60 & 75 & - & 90 & 84 \\
\hline 10 & $\mathrm{~N}_{300} \mathrm{P}_{0} \mathrm{~K}_{150}$ & - & 75 & 75 & 60 & 75 & 75 & 90 & - \\
\hline 11 & $\mathrm{~N}_{300} \mathrm{P}_{300} \mathrm{~K}_{300}$ & 180 & 150 & 75 & 60 & 75 & 150 & 90 & 120 \\
\hline 12 & $\mathrm{~N}_{300} \mathrm{P}_{270} \mathrm{~K}_{210}$ & 162 & 105 & 75 & 60 & 75 & 105 & 90 & 108 \\
\hline 13 & $\mathrm{~N}_{300} \mathrm{P}_{240} \mathrm{~K}_{180}$ & 144 & 90 & 75 & 60 & 75 & 90 & 90 & 96 \\
\hline 14 & $\mathrm{~N}_{300} \mathrm{P}_{210} \mathrm{~K}_{150}$ & 126 & 75 & 75 & 60 & 75 & 75 & 90 & 84 \\
\hline 15 & $\mathrm{~N}_{300} \mathrm{P}_{180} \mathrm{~K}_{120}$ & 108 & 60 & 75 & 60 & 75 & 60 & 90 & 72 \\
\hline
\end{tabular}

In this case: 1st option fertilizer-free control (NOP0K0), in the 2nd option the ratio of phosphorus and potassium to nitrogen is set as 1: 07: 0 , in the 3rd option N-1: P-0: K05, in the 4th option N-1: P-1 : K-1, 5-option N-1: P-09: K-07, 6-option N-1: P-08: K-06, 7option N-1: P-07: K-05, Option 8 has N-1: P-06: K-04 ratios. The same ratios were also taken into account in the $300 \mathrm{~kg} /$ ha options with increased nitrogen (Table 4).

According to the data in Table 4 above, irrigation and agrotechnical measures were carried out simultaneously with the remaining options for cotton grown in option 1 . Nitrogen in the form of nitrate in the soils of this option averaged $24.1 \mathrm{mg} / \mathrm{kg}$ in the drive layers before planting and $20.6 \mathrm{mg} / \mathrm{kg}$ at the end of the growing season. This means that as plants develop, they absorb a certain amount of nutrients from the soil, as a result of which the balance of nutrients in the soil changes. In option 2, where nitrogen was applied, the average N-NO3 before planting was $23.9 \mathrm{mg} / \mathrm{kg}$, while during the 2-3 leaf period it was $25.2 \mathrm{mg} / \mathrm{kg}$, and in the later phases it decreased to $13.1 \mathrm{mg} / \mathrm{kg}$ when it reached the flowering period. This situation was also observed in other options.

M. A. Belousov, F. Kh. Hashimov, Yu. T. Gritsevich, and H. T. Riskieva [1, 3, 5] were the first to study different norms, terms and ratios of mineral fertilizers in cotton growing, including in the conditions of Uzbekistan. Besides that, JS Sattarov, A. Ergashev studied the effect and dynamics of phosphorus mineral fertilizers on cotton in the conditions of typical and light gray and meadow soils irrigated with gray soils. When applying the norm of mineral fertilizers N200P140K100 kg/ha for 5 years, the typical irrigated gray soils are $37.5 \mathrm{~kg} / \mathrm{ha}$ in the driving layer, $5.7 \mathrm{~kg} / \mathrm{ha}$ under the drive, and $31.8-7.1 \mathrm{~kg} / \mathrm{ha}$ in the grassgrass soils, respectively, and in newly irrigated light gray soils for 3 years, when applied at the following rates, the driving and sub-driving layers were found to be around 41.8-20.4 $\mathrm{mg} / \mathrm{kg}$, respectively. The authors acknowledged that changes in mobile phosphorus in soils also depend on cotton navigation.

In China, researchers have conducted field experiments for many years at different rates and ratios based on the "wheat-corn" rotation system to increase the fertility of Typic Ustochept-saline sandy soils. At the same time, when using mineral fertilizers $\mathrm{N}_{0} \mathrm{P}_{0}, \mathrm{~K}_{270}$ and $\mathrm{N}_{540} \mathrm{P}_{67.5} \mathrm{~K}_{135}$ in different options, a significant increase in organic matter in the driving layers of the soil was observed from year to year [6].

In order to determine the laws of biokinetic circulation of the nitrogen element on the basis of the "soil-plant-fertilizer" system in 1985-2006, chestnut formed in Buryatia and Trans-Baikal regions, black, gray forest in the south and conducted experiments in grassy black soil conditions scattered on permanent glaciers. Experimental scheme: 1st option control, 2nd option R40K40 - background, 3rd option background $+\mathrm{N} 60$, in addition nitrogen-saturated fertilizers were applied. Noting that nitrogen is mobile in the 'soil-plantfertilizer' system, the authors found that its best balance was observed in gray forest soils, near-deficit condition was observed in chestnut soils, and positive in other soils [12]. 
Table 4. Dynamics of reactive nutrients, $\mathrm{mg} / \mathrm{kg}$

\begin{tabular}{|c|c|c|c|c|c|c|c|c|c|c|c|c|c|c|c|}
\hline \multirow{2}{*}{$\#$} & \multirow{2}{*}{ 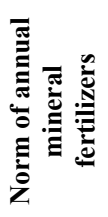 } & \multirow{2}{*}{ } & \multirow{2}{*}{ 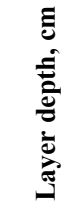 } & \multicolumn{3}{|c|}{ Pre-sowing } & \multicolumn{3}{|c|}{ First 3-4 leaves } & \multicolumn{3}{|c|}{ Flowering } & \multicolumn{3}{|c|}{ Blooming } \\
\hline & & & & $\mathbf{N}$ & $\mathbf{P}$ & $\mathbf{K}$ & $\mathbf{N}$ & $\mathbf{P}$ & $\mathbf{K}$ & $\mathbf{N}$ & $\mathbf{P}$ & $\mathbf{K}$ & $\mathbf{N}$ & $\mathbf{P}$ & $\mathbf{K}$ \\
\hline \multirow{6}{*}{ - } & \multirow{6}{*}{$\begin{array}{l}\hat{\theta} \\
0 \\
0 \\
2 \\
0 \\
0 \\
0 \\
0 \\
0\end{array}$} & \multirow{2}{*}{1} & $0-30$ & 24.9 & 19.7 & 227 & 23.8 & 17.6 & 212 & 20.1 & 15.7 & 187 & 10.2 & 12.1 & 155 \\
\hline & & & $30-50$ & 20.9 & 19.2 & 209 & 19.6 & 17.3 & 193 & 16.4 & 15.3 & 170 & 8.7 & 12.0 & 140 \\
\hline & & \multirow{2}{*}{2} & $0-30$ & 24.7 & 19.3 & 218 & 24.3 & 17.4 & 202 & 20.7 & 15.8 & 176 & 9.6 & 12.5 & 145 \\
\hline & & & $30-50$ & 19.8 & 19.0 & 200 & 19.7 & 17.1 & 186 & 16.3 & 15.4 & 168 & 8.4 & 11.3 & 138 \\
\hline & & \multirow{2}{*}{3} & $0-30$ & 22.6 & 20.3 & 221 & 22.5 & 18.3 & 204 & 18.4 & 16.3 & 179 & 10.6 & 12.9 & 146 \\
\hline & & & $30-50$ & 21.2 & 19.5 & 207 & 21.0 & 17.6 & 191 & 17.3 & 15.1 & 173 & 8.3 & 11.8 & 142 \\
\hline \multirow{6}{*}{$N$} & \multirow{6}{*}{ 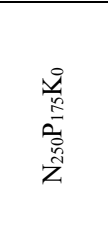 } & \multirow{2}{*}{1} & $0-30$ & 23.8 & 26.7 & 227 & 25.9 & 27.6 & 207 & 20.9 & 22.4 & 203 & 13.6 & 19.8 & 163 \\
\hline & & & $30-50$ & 18.7 & 25.3 & 210 & 20.3 & 26.3 & 190 & 17.6 & 20.8 & 186 & 10.9 & 18.4 & 149 \\
\hline & & & $0-30$ & 24.3 & 28.9 & 220 & 25.6 & 32.1 & 200 & 21.3 & 24.3 & 195 & 12.9 & 20.9 & 154 \\
\hline & & 2 & $30-50$ & 22.1 & 26.4 & 198 & 23.6 & 27.3 & 182 & 18.9 & 21.3 & 178 & 11.8 & 19.1 & 142 \\
\hline & & & $0-30$ & 23.5 & 30.7 & 200 & 24.1 & 31.4 & 179 & 20.5 & 24.9 & 174 & 12.7 & 22.6 & 138 \\
\hline & & J & $30-50$ & 21.3 & 27.6 & 191 & 22.9 & 28.7 & 174 & 18.6 & 22.7 & 170 & 10.8 & 19.8 & 135 \\
\hline \multirow{6}{*}{$\omega$} & \multirow{6}{*}{ 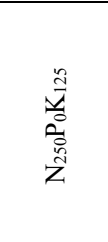 } & \multirow{2}{*}{1} & $0-30$ & 25.3 & 18.7 & 236 & 26.4 & 16.8 & 221 & 22.3 & 15.2 & 217 & 12.8 & 12.1 & 187 \\
\hline & & & $30-50$ & 22.0 & 17.6 & 201 & 22.3 & 15.4 & 187 & 18.6 & 12.9 & 182 & 11.5 & 9.7 & 164 \\
\hline & & 0 & $0-30$ & 24.1 & 20.1 & 227 & 25.1 & 18.1 & 214 & 21.4 & 15.7 & 207 & 13.6 & 12.1 & 183 \\
\hline & & 2 & $30-50$ & 19.3 & 19.3 & 215 & 20.1 & 17.6 & 201 & 16.3 & 15.1 & 196 & 12.4 & 11.7 & 169 \\
\hline & & 2 & $0-30$ & 24.6 & 19.6 & 240 & 24.9 & 17.4 & 223 & 21.1 & 15.3 & 214 & 12.4 & 11.8 & 186 \\
\hline & & J & $30-50$ & 22.3 & 18.7 & 210 & 22.7 & 16.8 & 194 & 19.2 & 14.2 & 187 & 10.9 & 10.7 & 164 \\
\hline & & & $0-30$ & 25.6 & 42.3 & 265 & 27.4 & 46.2 & 251 & 23.4 & 39.2 & 245 & 16.2 & 29.8 & 209 \\
\hline & ฉ & 1 & $30-50$ & 21.4 & 35.1 & 241 & 22.3 & 38.1 & 217 & 18.9 & 30.4 & 210 & 13.4 & 22.7 & 179 \\
\hline 4 & $\frac{1}{5}$ & 2 & $0-30$ & 19.8 & 40.5 & 257 & 21.6 & 44.2 & 243 & 25.1 & 36.4 & 236 & 17.4 & 27.6 & 202 \\
\hline 4 & & 2 & $30-50$ & 17.6 & 36.7 & 239 & 28.9 & 38.9 & 224 & 18.4 & 32.5 & 217 & 12.6 & 24.3 & 178 \\
\hline & z & & $0-30$ & 23.6 & 45.9 & 260 & 25.3 & 48.9 & 241 & 22.3 & 40.7 & 239 & 15.3 & 29.7 & 206 \\
\hline & & J & $30-50$ & 21.4 & 42.7 & 245 & 22.1 & 45.3 & 234 & 18.7 & 37.4 & 221 & 11.7 & 27.1 & 177 \\
\hline & & 1 & $0-30$ & 25.3 & 40.3 & 251 & 26.3 & 43.8 & 234 & 22.5 & 37.4 & 229 & 13.6 & 27.3 & 194 \\
\hline & & 1 & $30-50$ & 22.4 & 33.4 & 242 & 23.1 & 35.4 & 221 & 19.2 & 29.6 & 208 & 12.4 & 21.7 & 176 \\
\hline 5 & $\frac{y}{3}$ & 2 & $0-30$ & 19.9 & 39.6 & 249 & 22.1 & 42.1 & 226 & 19.6 & 35.4 & 224 & 12.3 & 26.8 & 189 \\
\hline 3 & os & 2 & $30-50$ & 18.6 & 37.4 & 241 & 20.4 & 39.7 & 215 & 16.8 & 32.4 & 207 & 10.6 & 24.1 & 174 \\
\hline & $\mathrm{Z}$ & 2 & $0-30$ & 23.5 & 38.1 & 253 & 23.9 & 40.8 & 231 & 20.4 & 34.8 & 224 & 11.8 & 26.7 & 185 \\
\hline & & $J$ & $30-50$ & 22.4 & 30.7 & 239 & 23.2 & 32.7 & 219 & 18.6 & 29.1 & 213 & 10.9 & 21.4 & 176 \\
\hline & & & $0-30$ & 26.4 & 36.7 & 250 & 27.4 & 39.3 & 224 & 22.1 & 34.7 & 219 & 14.2 & 26.9 & 179 \\
\hline & & 1 & $30-50$ & 21.9 & 32.9 & 237 & 23.1 & 34.6 & 218 & 18.6 & 29.7 & 205 & 11.6 & 22.4 & 167 \\
\hline 6 & $\frac{1}{8}$ & ? & $0-30$ & 24.3 & 39.1 & 241 & 25.3 & 41.3 & 221 & 20.3 & 32.4 & 216 & 13.6 & 24.6 & 176 \\
\hline & คि. & & $30-50$ & 20.4 & 29.8 & 223 & 21.3 & 32.1 & 197 & 17.4 & 27.4 & 191 & 11.1 & 20.9 & 163 \\
\hline & Z & 0 & $0-30$ & 23.8 & 30.6 & 245 & 25.1 & 32.4 & 217 & 21.6 & 28.9 & 213 & 13.2 & 22.7 & 174 \\
\hline & & 3 & $30-50$ & 19.8 & 26.8 & 233 & 21.4 & 29.7 & 196 & 18.9 & 25.7 & 189 & 10.9 & 19.9 & 164 \\
\hline & & & $0-30$ & 20.9 & 35.1 & 248 & 22.3 & 36.4 & 225 & 17.5 & 32.6 & 206 & 12.3 & 24.9 & 178 \\
\hline & à & 1 & $30-50$ & 17.8 & 30.7 & 240 & 19.3 & 32.1 & 214 & 16.3 & 28.4 & 198 & 11.4 & 21.6 & 162 \\
\hline 7 & $\frac{1}{n}$ & ? & $0-30$ & 23.7 & 32.6 & 235 & 24.1 & 34.9 & 212 & 18.7 & 31.6 & 224 & 12.9 & 24.6 & 187 \\
\hline t & 今. & 2 & $30-50$ & 20.6 & 29.8 & 233 & 20.4 & 31.8 & 210 & 16.2 & 27.6 & 214 & 10.8 & 19.8 & 174 \\
\hline & Z & 3 & $0-30$ & 25.3 & 34.2 & 241 & 25.3 & 35.7 & 218 & 18.1 & 31.6 & 223 & 12.5 & 24.6 & 181 \\
\hline & & J & $30-50$ & 22.4 & 30.8 & 224 & 23.4 & 32.9 & 198 & 17.9 & 28.7 & 207 & 11.9 & 20.1 & 168 \\
\hline
\end{tabular}




\begin{tabular}{|c|c|c|c|c|c|c|c|c|c|c|c|c|c|c|c|}
\hline \multirow{6}{*}{8} & \multirow{6}{*}{ 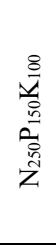 } & \multirow{2}{*}{1} & $0-30$ & 23.7 & 29.8 & 240 & 25.1 & 31.8 & 220 & 20.6 & 27.6 & 213 & 12.9 & 21.1 & 174 \\
\hline & & & $30-50$ & 19.5 & 26.7 & 233 & 20.3 & 28.4 & 210 & 16.9 & 24.3 & 197 & 11.2 & 18.4 & 163 \\
\hline & & \multirow{2}{*}{2} & $0-30$ & 23.4 & 30.1 & 238 & 24.8 & 32.6 & 215 & 22.4 & 28.4 & 224 & 13.6 & 21.7 & 178 \\
\hline & & & $30-50$ & 20.1 & 26.3 & 230 & 22.3 & 28.1 & 206 & 18.7 & 24.9 & 205 & 11.7 & 19.1 & 175 \\
\hline & & \multirow{2}{*}{3} & $0-30$ & 23.5 & 28.6 & 227 & 24.1 & 29.7 & 204 & 19.5 & 26.4 & 208 & 12.6 & 19.7 & 173 \\
\hline & & & $30-50$ & 19.7 & 25.9 & 225 & 19.8 & 27.6 & 197 & 15.6 & 23.9 & 196 & 10.8 & 18.3 & 163 \\
\hline \multirow{6}{*}{9} & \multirow{6}{*}{ 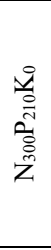 } & \multirow{2}{*}{1} & $0-30$ & 24.6 & 40.9 & 230 & 25.6 & 43.2 & 208 & 20.9 & 36.7 & 205 & 14.9 & 27.1 & 162 \\
\hline & & & $30-50$ & 20.5 & 40.0 & 204 & 21.7 & 41.8 & 193 & 19.6 & 34.5 & 186 & 12.6 & 25.8 & 142 \\
\hline & & 2 & $0-30$ & 27.3 & 41.9 & 215 & 27.9 & 44.3 & 194 & 22.4 & 38.1 & 189 & 14.3 & 28.6 & 140 \\
\hline & & 2 & $30-50$ & 21.5 & 35.8 & 210 & 21.7 & 38.4 & 187 & 18.6 & 32.9 & 179 & 12.1 & 24.3 & 135 \\
\hline & & 2 & $0-30$ & 24.9 & 42.7 & 216 & 26.3 & 44.6 & 192 & 22.3 & 37.4 & 182 & 14.2 & 27.9 & 139 \\
\hline & & 3 & $30-50$ & 20.9 & 30.9 & 207 & 21.4 & 32.1 & 183 & 19.3 & 26.9 & 174 & 12.6 & 19.7 & 129 \\
\hline \multirow{6}{*}{10} & \multirow{6}{*}{$\begin{array}{l}0 \\
\frac{n}{4} \\
0 \\
0 \\
\delta \\
z \\
z\end{array}$} & \multirow{2}{*}{1} & $0-30$ & 25.9 & 19.7 & 241 & 27.3 & 18.1 & 224 & 22.1 & 15.3 & 221 & 15.3 & 11.4 & 189 \\
\hline & & & $30-50$ & 20.4 & 19.2 & 230 & 21.4 & 17.4 & 213 & 17.4 & 14.7 & 208 & 11.9 & 11.0 & 176 \\
\hline & & 2 & $0-30$ & 25.1 & 19.3 & 235 & 26.3 & 18.3 & 218 & 21.3 & 15.2 & 214 & 13.6 & 11.3 & 189 \\
\hline & & 2 & $30-50$ & 20.4 & 18.6 & 207 & 21.5 & 17.2 & 192 & 17.2 & 14.3 & 189 & 11.7 & 9.8 & 163 \\
\hline & & 3 & $0-30$ & 24.1 & 20.1 & 218 & 25.3 & 18.4 & 201 & 20.6 & 15.4 & 196 & 14.2 & 10.9 & 167 \\
\hline & & $J$ & $30-50$ & 21.0 & 19.0 & 205 & 22.5 & 17.2 & 187 & 19.3 & 14.8 & 184 & 12.9 & 9.7 & 162 \\
\hline \multirow{6}{*}{11} & \multirow{6}{*}{ 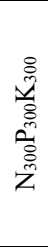 } & \multirow{2}{*}{1} & $0-30$ & 23.5 & 46.7 & 274 & 24.3 & 52.1 & 260 & 20.3 & 44.1 & 251 & 13.9 & 31.4 & 214 \\
\hline & & & $30-50$ & 20.3 & 41.6 & 245 & 20.9 & 46.9 & 239 & 18.4 & 38.7 & 234 & 12.4 & 27.3 & 201 \\
\hline & & 2 & $0-30$ & 24.1 & 45.1 & 269 & 24.6 & 49.2 & 254 & 19.8 & 41.2 & 251 & 13.8 & 29.4 & 214 \\
\hline & & 2 & $30-50$ & 19.4 & 38.9 & 254 & 20.3 & 43.6 & 246 & 17.6 & 36.8 & 239 & 12.5 & 25.1 & 201 \\
\hline & & 3 & $0-30$ & 20.7 & 43.9 & 278 & 21.4 & 48.2 & 263 & 20.6 & 40.4 & 256 & 14.2 & 29.4 & 214 \\
\hline & & 3 & $30-50$ & 18.6 & 40.1 & 263 & 19.8 & 44.7 & 248 & 17.2 & 27.3 & 239 & 12.3 & 21.6 & 209 \\
\hline \multirow{6}{*}{12} & \multirow{6}{*}{ 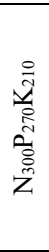 } & \multirow{2}{*}{1} & $0-30$ & 19.5 & 45.3 & 249 & 21.1 & 48.6 & 221 & 16.5 & 42.1 & 217 & 12.6 & 31.7 & 178 \\
\hline & & & $30-50$ & 17.9 & 36.9 & 241 & 19.2 & 39.6 & 219 & 15.6 & 33.5 & 208 & 11.4 & 27.6 & 169 \\
\hline & & 2 & $0-30$ & 25.3 & 47.1 & 253 & 25.3 & 49.6 & 224 & 20.4 & 32.4 & 223 & 15.3 & 33.9 & 178 \\
\hline & & 2 & $30-50$ & 22.4 & 40.1 & 244 & 24.6 & 41.3 & 216 & 18.9 & 30.8 & 216 & 14.2 & 24.1 & 169 \\
\hline & & 3 & $0-30$ & 24.6 & 41.2 & 253 & 24.8 & 44.2 & 228 & 19.7 & 37.1 & 226 & 14.9 & 29.7 & 186 \\
\hline & & 3 & $30-50$ & 20.3 & 36.7 & 231 & 22.3 & 38.1 & 209 & 17.6 & 34.9 & 214 & 12.8 & 25.4 & 174 \\
\hline & & 1 & $0-30$ & 23.9 & 44.3 & 247 & 24.3 & 46.3 & 221 & 19.6 & 39.5 & 215 & 12.9 & 29.5 & 174 \\
\hline & $\nsubseteq$ & 1 & $30-50$ & 20.4 & 40.6 & 233 & 22.1 & 41.7 & 209 & 17.5 & 35.4 & 200 & 11.6 & 24.3 & 168 \\
\hline 13 & $\frac{d}{q}$ & 2 & $0-30$ & 25.1 & 39.8 & 247 & 25.9 & 42.1 & 218 & 20.6 & 36.2 & 214 & 13.8 & 26.1 & 169 \\
\hline 13 & ก) & 2 & $30-50$ & 23.6 & 32.9 & 241 & 23.4 & 34.8 & 205 & 18.7 & 29.4 & 205 & 12.4 & 21.7 & 157 \\
\hline & Z & 2 & $0-30$ & 23.7 & 39.1 & 253 & 24.8 & 40.9 & 230 & 19.3 & 35.8 & 223 & 12.7 & 25.3 & 176 \\
\hline & & 3 & $30-50$ & 20.9 & 36.5 & 247 & 21.8 & 38.6 & 224 & 17.2 & 32.9 & 217 & 10.9 & 22.7 & 169 \\
\hline & & 1 & $0-30$ & 23.6 & 38.7 & 241 & 24.7 & 38.9 & 217 & 19.6 & 32.6 & 214 & 13.9 & 22.1 & 167 \\
\hline & $\stackrel{\circ}{7}$ & 1 & $30-50$ & 20.7 & 36.9 & 247 & 21.3 & 37.6 & 210 & 16.8 & 31.4 & 203 & 12.5 & 19.9 & 156 \\
\hline 14 & 证 & 2 & $0-30$ & 21.6 & 39.4 & 249 & 22.6 & 40.7 & 224 & 17.6 & 34.7 & 217 & 12.9 & 24.7 & 163 \\
\hline 14 & 8 & 2 & $30-50$ & 20.8 & 37.1 & 238 & 21.4 & 38.3 & 216 & 16.3 & 32.6 & 206 & 10.8 & 22.3 & 157 \\
\hline & Z & 2 & $0-30$ & 26.4 & 36.4 & 236 & 27.3 & 37.6 & 229 & 20.4 & 31.7 & 219 & 13.6 & 22.4 & 168 \\
\hline & & 3 & $30-50$ & 20.7 & 34.3 & 224 & 21.9 & 35.4 & 200 & 17.9 & 29.8 & 198 & 12.3 & 19.8 & 151 \\
\hline & & 1 & $0-30$ & 23.4 & 36.7 & 241 & 24.6 & 37.9 & 218 & 20.1 & 29.8 & 214 & 11.9 & 23.4 & 172 \\
\hline & & 1 & $30-50$ & 20.4 & 34.2 & 224 & 21.4 & 34.3 & 203 & 16.9 & 27.4 & 197 & 9.8 & 19.3 & 159 \\
\hline 15 & $\underset{\infty}{\mathscr{D}}$ & 2 & $0-30$ & 24.6 & 35.8 & 239 & 25.3 & 36.9 & 211 & 19.4 & 29.6 & 206 & 11.2 & 22.4 & 164 \\
\hline 10 & ) & 2 & $30-50$ & 20.3 & 33.5 & 231 & 21.1 & 34.7 & 208 & 17.2 & 27.3 & 200 & 9.6 & 18.3 & 158 \\
\hline & $\bar{Z}$ & 3 & $0-30$ & 23.9 & 34.1 & 248 & 25.3 & 31.9 & 216 & 19.6 & 25.8 & 217 & 10.7 & 17.9 & 175 \\
\hline & & 3 & $30-50$ & 20.7 & 28.3 & 239 & 21.7 & 28.7 & 210 & 17.4 & 22.9 & 202 & 8.9 & 16.8 & 163 \\
\hline
\end{tabular}


In the first control option of the experiments conducted by Ukrainian researchers $[7,12]$ to study the nitrogen element turnover in agriculture, when combined with the application of mineral and local fertilizers $\left(\mathrm{N}_{40} \mathrm{P}_{36} \mathrm{~K}_{40}+6 \mathrm{t} /\right.$ ha fertilizer $)$ and found that the amount of nutrients that went out with the crops of beet crops was high. In the control option, -74.3 $\mathrm{kg} / \mathrm{ha}$, and in the option using mineral and local fertilizers, $-66.8 \mathrm{~kg} / \mathrm{ha}$ of additional nitrogen was released.

A. S. Merzlikin [12] noted that the role of mineral and local fertilizers in increasing crop yields and soil fertility is invaluable. For example, American scientists estimate that 41 percent of crop yields are due to mineral fertilizers, 13 to 20 percent to herbicides, 15 percent to favorable weather, 8 percent to variety, 5 percent to irrigation, and 11 to 18 percent to other factors. German scientists say that $50 \%$ is the share of fertilizers, French scientists say $50-70 \%$, and Russian scientists say $50-60 \%$.

\section{Conclusion}

The geological structure of the Kashkadarya basin is very complex, surrounded by the Zarafshan and Hissar ridges and has unique climatic features. The soil and climatic conditions of this basin and the culture of agriculture have a special character. Typical irrigated gray soils in the field experiment account for $36 \%$ of the irrigated soils in the Kashkadarya Basin. The studied irrigated typical gray soils consist mainly of medium sandy soils in the genetic layers, and heavy sandy mechanical soils in the lower 120-217 cm layers. In terms of mechanical fractions, large dust particles predominate. The fact that the 0-120 cm layers in which the main root system of crops develops consists of a medium sandy mechanical composition creates favorable water and nutrient regimes for their growth and development. In the driving layer of soils, humus is around $1.094 \%$, total nitrogen is $0.080 \%$, total phosphorus is $0.168 \%$, total potassium is around $1.07 \%$, mobile nitrogen, phosphorus and exchangeable potassium belong to low and moderately supplied groups.

Nitrate in the form of nitrate in the soils of the field experiments averaged $24.1 \mathrm{mg} / \mathrm{kg}$ in the driving layers of Option 1 before planting and $20.6 \mathrm{mg} / \mathrm{kg}$ at the end of the growing season. In option 2, where nitrogen was applied, the average $\mathrm{N}-\mathrm{NO}_{3}$ before planting was $23.9 \mathrm{mg} / \mathrm{kg}$, while during the 2-3 leaf period it was $25.2 \mathrm{mg} / \mathrm{kg}$, and in the later phases it decreased to $13.1 \mathrm{mg} / \mathrm{kg}$ when it reached the flowering period. This situation was also observed in other options. Under these soil conditions, a scientifically based nutrient environment is created for the variety by determining the nutrient requirements of the promising cotton variety "Porlok-4". This allows to get a quality and weighty harvest, fully demonstrating the potential of the variety.

\section{References}

1. J. Kuziev, Development of a new geophase-smart system of fertilization technology based on specific factors in irrigated agriculture, 128 (RISSC Press, Tashkent, 2020)

2. Cotton Handbook, 539 (Fan Press, Tashkent, 2016)

3. J. Kuziev, Improving the agrochemical condition of irrigated soils in the gray soils of the Kashkadarya basin, 154 (RISSC Press, Tashkent, 2017)

4. Methods of conducting field experiments, 147 (UzPITI Press, Tashkent, 2017)

5. B. Shokirov, M. Mirakov, B. Murodov, High yield technology in cotton growing, 72 (Nasaf Press, Karshi, 2010)

6. L. Niu, J. Hao, Z. Ding, X. Li, X. Niu, B. Zhang, Pedosphere 15(5), 669-675 (2005) 
7. L. Budazhapov, I. Lavrova, J. Agrochemistry 3, 5-9 (2007)

8. S. Isaev, I. Begmatov, G. Goziev, S. Khasanov, IOP Publishing 883(1), 012080 (2020)

9. S. K. Isaev, R. U. Rakhmatov, S. S. Tadjiev, G. I. Goziev, S. Z. Khasanov, IOP Publishing 614(1), 012147 (2020)

10. R. A. Kulmatov, S. A. Adilov, S. Khasanov, IOP Publishing 614(1), 012149 (2020)

11. A. Jumanov, S. Khasanov, A. Tabayev, G. Goziev, U. Uzbekov, E. Malikov, IOP Publishing 614(1), 012150 (2020)

12. A. S. Merzlikin, J. Agrochemistry and ecology problems 1, 45-54 (2010) 